\title{
RECENT PORTUGUESE LEGISLATION ON THE NEGRO LABOUR QUESTION IN PORTUGUESE AFRICA
}

\author{
[Translated and Summarised by SIR HARRY JOHNSTON.]
}

IN the Portuguese Province of Cape Verde in IgoI it was thought necessary to take measures to avoid or to attenuate accidents connected with machinery for the manufacture of sugar where natives of Africa were working, especially women and children. All buildings and manufactories connected with the sugar industry must be clean, properly ventilated, and provided with the necessary sanitary appliances. No male children under the age of twelve and no females under the age of twenty-one may be under any circumstances employed in night work. Throughout these Provisions male workers are considered to be children until they have attained the age of sixteen years.

In December 1902 the Colonial Office was authorized to reform the legislation relative to the engagement of Negro workers in the Province of Saó Thome and Principe ${ }^{1}$ in such a way as to facilitate and safeguard contracts for the repatriation of labourers at the end of their term of service, proper care being taken of them during that period, ano a reasonable minimum of gain assured to them at the time of their repatriation. On the 3 Ist of January 1903 it was thought necessary to take special measures to provide that there should be no lack of Negro labour in the islands of Sao Thome and Principe in order to properly develop the tropical agriculture of those

\footnotetext{
1 Two small but very fertile Portuguese Islands under the Equator in the Gulf of Guines. The interior of $\mathrm{Sad}$ Thome is very elevated,'and is quite healthy for European colonirts-Editor.
} 
THE NEGRO LABOUR QUESTTON IN PORTUGUESE AFRICA I67

islands, and the following decree was published and put into force.

Article I provides that the recruitment and migration of natives of either sex is permissible in the provinces of Angola, Guinea, Moçambique, and Cape Verde if their destiny is domestic, industrial, or agricultural service in the Province of Saõ Thome and Principe, provided that the recruitment takes place at the authorized agencies, and is subject to the conditions of the present Decree. At the same time it is also permitted to import into the islands of Sao Thomé and Principe Chinese: coolies from Macao (the Portuguese possession in China, near Hong Kong).

(2) The Government may itself send such Negro labourers from Angola as may volunteer to work in Saó Thomé and Principe, and similar measures may be taken to obtain and forward under like conditions workers from Moçambique, Cape Verde, and Guinea to Saס̃ Thomé and Principe.

(3) Requests for Negro workers must be presented in writing on a prescribed form between the ist and the 15 th days of June or of December to the Curator-General who presides over the Department of Colonists and Workers in Saõ Thome, or to his Delegate in the island of Principe. By one or other of these officials these requests for labourers will be registered, and on these requests will be noted by the officials in question the capacity which the petitioners may possess for properly carrying out their contracts with the Negro workers. These petitions will then be forwarded to the Secretariat of the Sao Thome andPrincipe Government. ...

(4) The requirements of the Negro workers will be regulated in the following terms. If they are for agricultural service, one adult man or woman will be supplied for each hectare of land ; if as domestic servants, as many as three will be supplied for each family of planters or settlers.

(5) In harmony with these requests the Provincial Government will fix on the 3oth day of the months of December and June the contingent of immigrant labourers which the Province requires. For example, during the first six months of the year following the bringing into force of these Regulations the total contingent may be fixed at 3,000 workers. The distribution 
during these six months will be carried out by the orders of the Provincial Government as much as possible in harmony with the requests made. (Here follow details of the way in which the distribution will be made)

(6) There will be founded in Lisbon a Central Commission to deal with the questions of the emigration and work of the labourers engaged under contract for Saõ Thomé and Principe. This Commission will be presided over by the Director General of Colonial Affairs or such official as he may designate, besides other commissioners from the Colonial Office and four landed proprietors of Saõ Thomé and Principe (elected by the landed proprietors of those islands) whe are residents in Lisbon. Founded by and emerging from this Central Committee, there will be also established in the city of Saõ Thomé a local committee dealing more directly with the same subject, which will be presided over by the Curator-General of colonists and 'coolies' which will also contain delegates appointed by the Central Commission sitting at Lisbon. This local committee in Saó Thomé amongst other attributes will have power to keep and administer the funds collected from the planters. This general fund of money must be banked in the Colonial Bank of Saõ Thomé or its agency in Principe.

The local committee will also appoint emigration agents throughout Portuguese Africa and Macao.

It will draw up the maps or charts for distributing the workers amongst the planters, and will carry out this distribution. It will also watch over the strict fulfilment of the contracts made with these Negro labourers, especially all that has regard to lodging, food, medical treatment, repatriation, and renewal of contracts. [Many regulations follow providing for the fair distribution of engaged labourers amongst the applicants. No one will be permitted to receive in the same six months more than two hundred workers under contract.]

(7) The agencies which are appointed in various Portuguese possessions for the recruitment of labour must first obtain official licences to act as such from the Governor of the province or district in which they work. They have to deposit caution money to the value of about $£ 100$. Every agent must pay for his licence a tax of (about) two shillings for each Negro worker 
that he engages and despatches to Sao Thomé, provided that the sum thus payable annually on these licences shall not be less than $£ 10$ a year, while each Agent's licence is charged with stamp duty to the value of (about) $\delta I$. In compensation for these payments, however, the agents are exempted from a certain local tax imposed on industries. The sums thus collected form part of the revenues of the province or district. These licences may be revoked at any time by the Governor of the province without compensation. The recruiting agents must have nothing whatever to do with local government or politics, and must use every reasonable means of preventing illicit emigration. They must also beware of making any mistakes as regards the proper naming and identifying of the natives who contract for service, and they must be equally on their guard against employing any violence or fraudulent means for inducing workers to engage.

(8) All contracts with labourers must be made before public judicial authorities authorized to deal with such questions, and in foreign ports the Consular officials of Portugal may exercise similar functions in presiding over the conclusion of contracts. Every contracting labourer will receive a copy of his registration and a metal medallion with his registered number, date of contract, and indication of the agency where the contract was made. Copies of these contracts will be sent simultaneously with the despatch of the labourers to the Curator of Labour in Sao Thome or Principe. Each contract and its registration will be paid for by the agent to the local authorities or to the Consulate (if in a foreign port), the fee being about six shillings.

The following persons in Sao Thomé or Principe have the right to obtain workers under contract :-(1) A freehold or leasehold proprietor of an estate of not less than five hectares; (2) Any merchant or manufacturer; (3) Proprietors of vessels of not less than four tons burden. All applicants must be able to show that they pay direct or indirect taxation in the Province of Saõ Thomé and Principe of not less than $£_{3}$ per annum, and that they are actually engaged in business.

(9) When signing the contract each labourer shall be allowed to receive from the emigration agent an advance of wages not exceeding two months' pay in the presence of a competent 
official. Once this payment has been made the engaged labourer remains under the charge and control of the emigration agency until he is put on board ship for his destination.

(Io) Labour contracts may be drawn up for a maximum period of five complete years, counted from the day on which the workers are registered at the port of arrival. The least period for which a contract of service may be made in the Province of Moçambique is one year; in Portuguese Guinea and Cape Verde the least period is two complete years. It may be stipulated in the contracts that a part of the workers' pay may be from time to time deposited in the coffers of the Department of Public Works at the port of departure, so that it may be at regulated periods distributed to the families of the emigrants.

(iI) On board of all the ships that are to transport time-expired labourers who are to be repatriated a Government commissioner appointed by the Governor of Saõ Thomé shall travel, carrying with him the sums of accumulated wages due on repatriation, and charged with the task of verifying the disembarkation at the right port of each labourer, to whom he shall deliver the deferred pay due in the presence of the commander of the ship and of two witnesses. The transport of these labourers may only take place on Portuguese steamers registered for this purpose, or by foreign ships duly authorized by the Governor of Saõ Thomé on the understanding that the captains thereof agree to carry out all regulations applicable to these questions. (Here follow regulations governing the proper accommodation of labourers on board the ships going to and proceeding from Saõ Thome. During the passage the sexes are completely separated, and the taking on board of any aged, sick, or crazy person is prohibited. Especially is it forbidden to take on board any one who may seem to be suffering from Sleeping Sickness. All labourers taken on board ship unless they show signs of having already had small-pox must be vaccinated.

(12) The monthly pay of each recruited worker shall not be less than (about) ten shillings ${ }^{1}$ in the case of the men, and (about) seven shillings for each woman. All labourers shall be paid

1 The sums are naturally given in the Purtuguese coinage, and the rale of this varying from time to time, the writer only gives the approximate value in Engl money. 
monthly by their cmployers twa-fifths of the minimum fixed salary, this payment being made on the first Sunday or Monday after the termination of the month. The remainder of the salary will be paid into the Repatriation Fund administered by the Committee, to form the total "bonus" of deferred wages which will be paid to the labourers on their repatriation. Out of this fund also may be taken the allowances which labourers may wish to send to their families.

(13) Employers are obliged to furnish to each servant thus engaged free lodging (which must be sanitary), food, clothing, and treatment in sickness. Masters are also obliged to pay at the termination of the contract the expenses of the return passage of the labourers to their homes. The bonus or accumulated wages will be paid to the labourers on board ship (as before mentioned) at their arrival at their home or port of disembarkation; but this bonus or accumulated wages will only be paid to the workers who shall have finished the complete term of their contract. It is these also alone who will be able to claim free travelling expenses back to their homes. Employers will pay into the Repatriation Fund every three months the whole amount of wages due to their labourers after the deduction of the two-fifths paid to them direct. The emigration agents and all local authorities are held responsible for the arrival of the labourers in their homes at the end of their term of service, without loss of wages due to fraud or violence. In calculating the complete time of the contract regard is had to periods of leave of absence or to wilful desertion, which are deducted from the legal term. Labourers must be paid, however for periods of legal absence from work, but not when they are ill or are absent without leave. At the expiration of the legal term of contract the worker may if he pleases make a new contract without being repatriated, but he may only do so for at least a ten per cent. increase in salary, and during the new contract he will receive every three months from the Repatriation Fund a sum equivalent to six per cent. of his accumulated wages under the old contract, while the total sum of this bonus or accumulated wages under the old contract remains intact. Every employer of more than fifty labourers or non-European settlers is obliged to maintain separate infirmaries for sick labourers of 
both sexes, where they may be treated in a proper manner and gratuitously by qualified attendants, unless there be a suitable hospital not more than ten kilometres distant. All establishments of contracted settlers or labourers are to be visited one or more times a month (according to numbers) by a qualified medical man, who may prescribe anything he thinks proper for the well-being of the workers, even if it be complete abstention from work. Women labourers are to be relieved from all work (without loss of pay) for a period of thirty days preceding and following their accouchement; and for a long period after the accouchement they are to be put on light work if suckling the child.

There are many provisions regulating the conditions of labour with a view to preventing as much as possible unhealthy employments being forced on labourers or unsuitable work being given to children.

Natives of the islands of Saõ Thomé and Principe who might come under the legal definition of vagrants can at the discretion of the local governments be compelled to contract themselves for agricultural work in either of those islands.

H. H. Johnston.

Note.-The original decrees are pullished in the Dinrin do Governo, Lishon, Augast 26, 1901; 29th Dec. 1902; and 31st January, 1903. 